\title{
小特集 超音波画像技術
}

\section{2. 超音波画像技術の応用}

\author{
2-1 医学の応用 \\ 一一゚ルス反射法による生体映像法の現状——
}

竹 原 靖 明广

\section{1. まえがき}

近代医学の開花は, 診断学, とくに生体㬴像法の進歩 に負うところがきわめて大きい. しかし，乙れらの生体 映像法には, 正確な情報を与える一方, 被検者何何らか の苦痛や障害を与える欠点も有していた.

超音波検查は, 無痛で障害も皆無に等しいうえ, 軟部 組織の解像力に優れ, さらに電子スキャンなどの開発に よって, 心指や呼吸によって運動する臟器の断面がリア ルタイムで観察で音るようになり, 新しい生体映像法と して高い臨床評価を受けている。本稿では，この中心的 存在であるパルス应射法による起音波晾断の現状につい て紹介する。

\section{2.パルス反射法による超音波診断の歩み}

医学の世界では打猃法や聴診法にみられるように，音 は古くから診断に利用されていた，超音波という聞くこ とを必要上しない音在診断学の分野に導入したのは1940 年代になってからで， K. T. Dussik (1942〜49，オース トリア）の報告をすって喨矢とされている，ての内容 は，超音波を透過して脳室系壳描写するもので，猃断に 貢献するほどの成果は得られなかった。しかし，診断学 の分野任超音波之いう波動在導入し, 生体㳄部組織の描 写能力についてX線に優るととを立証して，今日の超音 波診断への端緒を開いたという点では画期的な研究であ った.

現在，超音波龍断の主流をなしているパルス反射法に 関する研究は, 1950 年に入ってから J. J. Wild, G. T. Ludwig 扔よび D. H. Howry らによって着手された。 一方，わが国に扔いても，ほほ時を同じくして蒌池，田 †関東中块病院

"Clinical Application of Ultrasound" —Diagnostic Imaging by Pulse Reflection Nethod_-." by Yasuaki Takehara (Kanto Central Hospital, Tokyo)
中，和賀井，内田らによって開始された，乙の時期に使 用された機器は, 金属用超音波探傷器に少し手を加えた 程度の $\mathrm{A}$ モード表示装置で, 頭蓋内構造の描写执よで脳 腫癔などの検出に主力が注がれた，当時は透過法と反射 法が並行して研究され, その有用性について諭議が盛ん であったが，1956 年，ケンブリッジで開かれた国際音響 学会議を境にパルス反射法が主流の座を占め, 今日に至 っている.

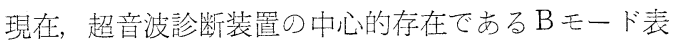
示は, 1952 年, J. J. Wild が, tow dimentional echoscope 上よばれるChamber 式の水浸法で乳房の描写に成 功したの老はしりに登場してきた。 D. H. Howryはセ クター走查で摘出した肝の断面を描写 (1952), ついで Somascope と四ばれる comfound circular scanning を 発表した (1957)。また菊池らは水浸法で脳の断面像を 描写, この方式を Ultrasono-Tomography と命名した (1956).

現在，腹部，産婦人科領域で広く利用されている接触 複合走查法 (Contact Compound Scan 以下 C. C. Scan) は I. Donald (1958)によってはじめられ，超音波診断 装置の歷史に一頁を開いた。 1960 年に入り G. Kossoff は水浸法で Arc sector scan を行い, 胎呪を鮮明に描写 し，乙の原理を搪大して 1975 年, 全自動で乳房や腹部 の断面像老描写するU. I. Octoson を開発した.

最近, 普及の兆老せている泌尿器科領域の超音波診 断の中心的存在である経直腸的ラジアル走查法は, 高 橋, 大内 (1964) によって着手され, 渡辺ら (1967) に よって改良が扣えられ，実用化への端緒が開かれた。

電子走査形装置は 1971 年, Bom らや内田らにより開 発され，とくに内田らの方式は現在，広く利用されてい るリニア電子走査形装置（以下リニア電子スキャン）の 基本形をなすすのである、ついで飯沼ら（1975）は, 彼 らの装置の欠点といわれる走査線密度や方位分解能の向 
小特集 $\square$ 超音波画像技術

上に力点をおいた高分解能を有する装置の開発・実用化 亿成功した.

電子スキャンには，リニア走查形とセクター走査形が あり, 主として前者は腹部全般の, 後者は循環器領域の 䧐断供され，咋今の爆発的普及の原動力となっている. また，探触子種々の改良が加えられ，臟器穿刺術，術 中彰断法，集団検診，および体腔式診断など多方面で活 用されている.

M モードは，スウェーデンの Edler や Hertz(1954〜

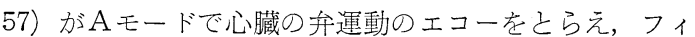
ルムを一定速度で流して記録したことに始まるとされて

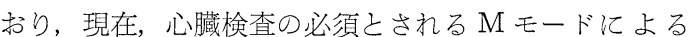
U. C. G. (Ultrasound Cardiography)への道が開けた.

3. 超音波診断装置の種類とその臨床応用

\subsection{A モード表示装置の臨床応用}

このようにパルス反射法による診断は，まずAモード に始まり，次いで Bモード，Mモード表示と発展してき た．乙の方式によって表示されるエコーパターンは，被 検対象物の大きさや距離の計測には便利であるが，1次 元像であるため客観性や再現性がそしく，現在では種々 の計測の他は一部の施設で頭部検查に利用されているに 過ぎない。

この方法は, 正中線エコー (midline echo) の変移の 有無により, 頭蓋内の占拠性病変, たとえば血腫や腫癔 の存在診断にスクリーニング的に利用されていたが，X 線 C. T の登場により衰微の一途を辿りつつある (写真 1).

\subsection{B モード表示装置の臨床応用}

（1）画像の変䢱

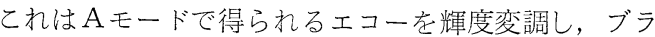
ウン管などにエコーの強さ（振幅の大きさ）に応じた明 るさの強弱で表示する方式である。したがって，ての方 式ではビームの入射する方向と走査する方向からなる 2 次元像，すなわち断面像が得られる。乙の種の装置によ

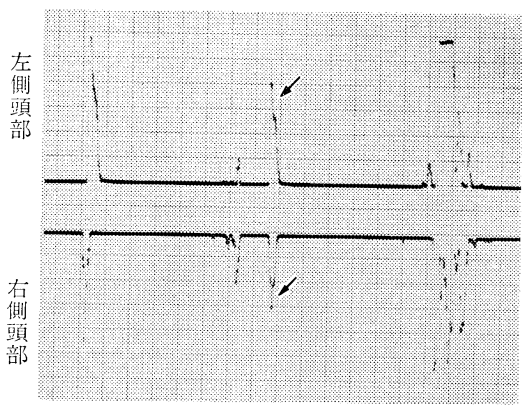

写真 1 Aモード表示，2 素子法によるミッ ドラインエコー $(\swarrow)$

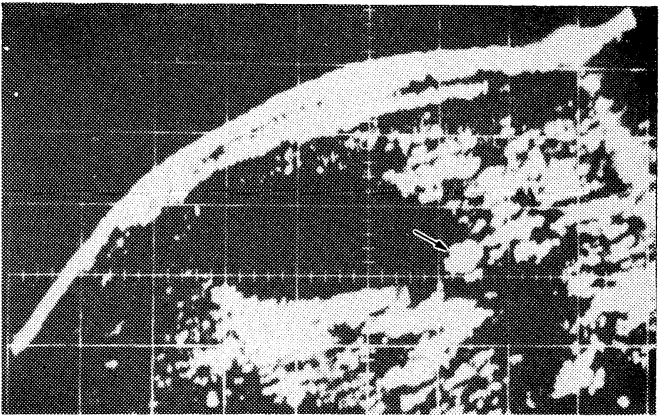

写真 2 ダイナミックレンジのせまい装置で撮った胆 石症 $(\swarrow)$ のエコーグラム
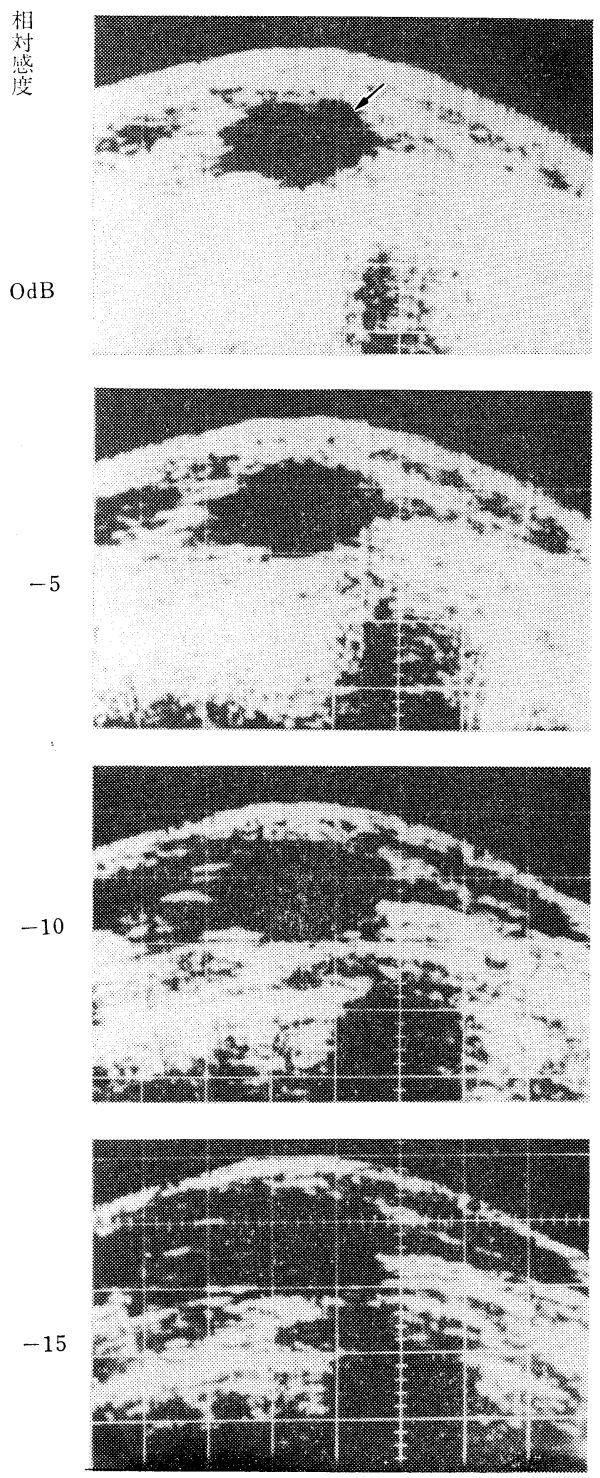

写真 3 感度断層法による乳癌のエコーグラム 


\section{2. 超音波画像技術の応用}

る断面像には，画像の表示の仕方にいくつかの変遷があ った。 初期の装置は分解能が覀いうえに, 堌幅器の増幅 度やブラウン管の表示能力にも限界があり, 表示像は中 間調が少なく階調性の之しい白黑の像として表示された

\section{(写真 2 ).}

このような白黒の階調のダイナミックレンジの狭い装 置では, 生体内部加ら返ってくる種々の強さのエコー を，1枚の表示像のなかに描き出すことは不可能であ り，また同一物を表示させても感度のわずかな変化によ って表示パターンが大きく変化する欠点があった．この ような欠点を補い，かつパターン認識を共通の立場から 論議できるようにするために，1965 年菊池によって“感 度断層法” (sensitivity graded tomography) なる方法 が提案された。

この方法は, エコーグラムの読影に感度の次元を加え ようとしたもので，AモードやBモードで得られるエコ 一の強さをある程度, 定量的に把握でき, また, 一定の 感度変化によって得られる一連のパターンを 1 つのグル ープとして読影の資料に供するため, 情報量が著しく増 加するという利点があり, 日本独自のすぐれた診断法と して，現在もなお一部で利用されている(写真了).

一方, 井出らは, 生体から返ってくる種々の強さのエコ 一を1枚の表示パターンの中にエコーレベルに応じた白 黒の明暗の濃淡として表示する方式について報告し, 和 賀井はその臨床応用における有用性を発表した（1967〜 68).

1973 年, 第 2 回世界超音波医学会議において, オース トラリアの G. Kossoff はグレイスケールェコーグラフ ィーと称して，階調性のすぐれたエコーグラムを発表 し，世界的な脚光を浴びた. とのような画質の改善は分 解能の向上と相まって, 超音波診断機器への評価を著し
く高めた。

このグレイスケールエコーグラフィーに続いて，リア ルタイム表示装置を代表する高分解能の電子スキャンが 開発され，超音波診断の有用性を不動のむのとした．電 子スキャンは探触子の操作がきわめて簡便であるため, 検查時間は短く，また像の描写に熟練を要さず，運動す る臓器の動態をリアルタイムに観察できる利点があり, 心臓, 血管, 肝胆道系, 産科执よび泌尿器科領域の診断 に不可欠のものとなっている.

（2）その臨床応用

Bモード表示装置には，手動走査形，機械走査形，抒 よび電子走查形の 3 種類があり(表1)，広汎な領域の診 断に供されている。 またてれら 3 種類の装置には，㭘査 目的亡する臟器に適するよう走査方式がつくられて打 り(図1)，次のような領域で活用されている.

（a）乳腺，甲状腺の検査 この領域の超音波検査 には，むっぱら水浸法が用いられている。乙の方法は， ごく薄いビニール製の水袋に脱気水を入れ，乙れを前頸 部 (甲状腺) や乳房の皮膚に密着固定し，乙の中を探触 子が自動的に低速で走査して断面像を描かせるすのであ る. この場合の探触子の走查方式には，リニアスキャン とアークスキャンがあるが，最近では後者が多用されて いる(写真 4 ).

現在の装置は，探触子の走査する範囲が狭いため，触 診によって腫熘などの存在部位を確かめた後, その質的 判定のために使用されているが，最近電子スキャンの技 術を導入して，走査範团の広い触診を前提としない集団 検診用の装置が開発されている。

(b) 循環器領域の検査最近, 機械的あるいは電 子的に高速度でビームを走査させる装置，すなわち高速 度メカニカルスキャンや電子スキャンが開発，実用化さ

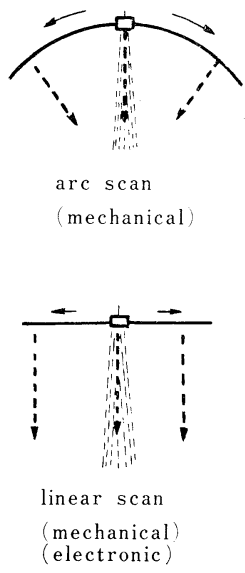

第 35 巻 第 1 号 (1981)

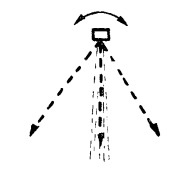

sector scan

(mechanical) (electronic)

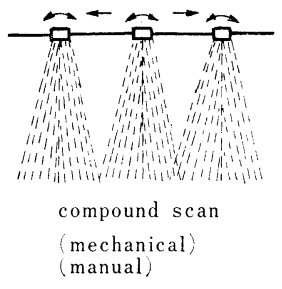

図 1 走査方式の種類
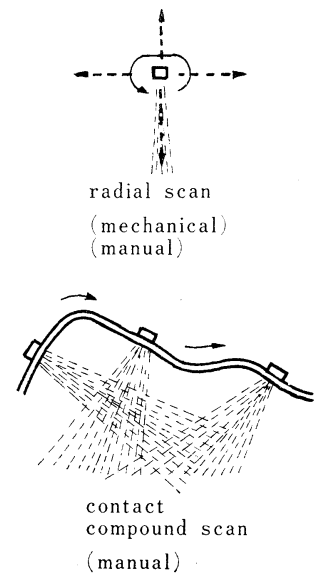

(manual) 


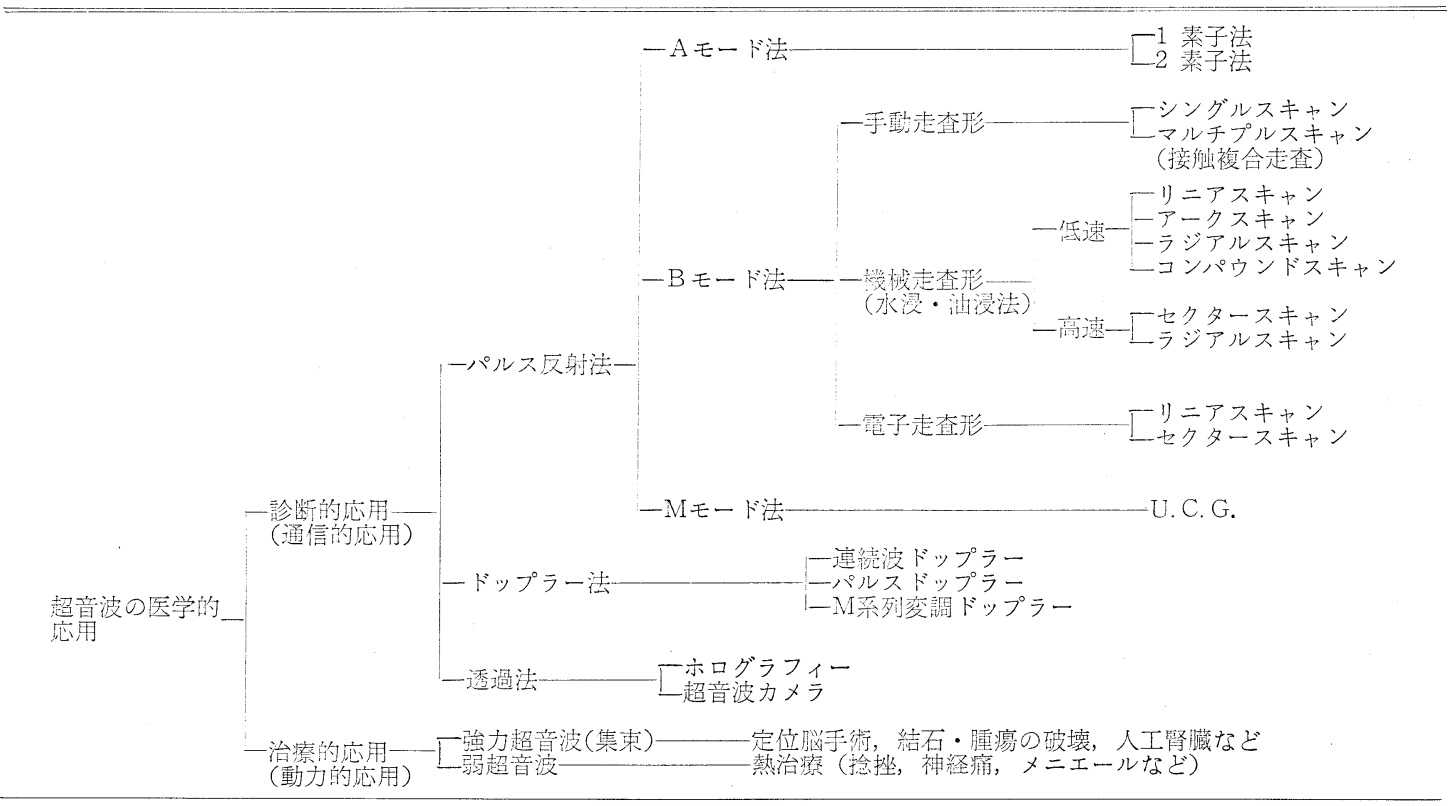

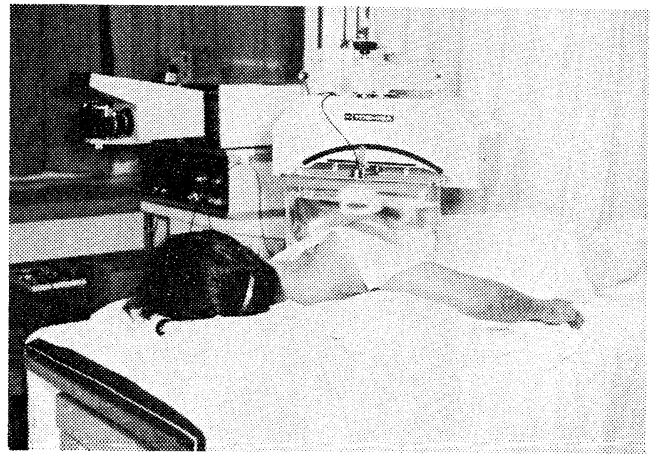

写真 4 水浸法, アーク走査方式による乳房検查

れ，心臟の運動する断面を実時間で観察記録できるよう になった，この種の装置にはリニアスキャンとセクター スキャンがあるが，心藏の検査では，助間という狭い echowindow から広い範囲の情報を得る必要があるた め, 主としてセクタースキャンが活用されている(写真 $5)$.

この領域では，徉来からMモードによる U. C. G. が 活用されている.乙れは弁運動などを 1 次元的に表現し たあのであるが，乙れに2 次元の像が得られるこれらの 装置が加わり, U. C. G. と共に循環器領域では欠くこと のできない検査法になっている.

ここで最近の話題のひとつである Contrast Echocardiography について紹介する. ての方法は 1969 年 Rochester 大学の Gramiak らによって提喝されたむので, 心腔内にエコーを発生させるコントラスト剤を注入し,

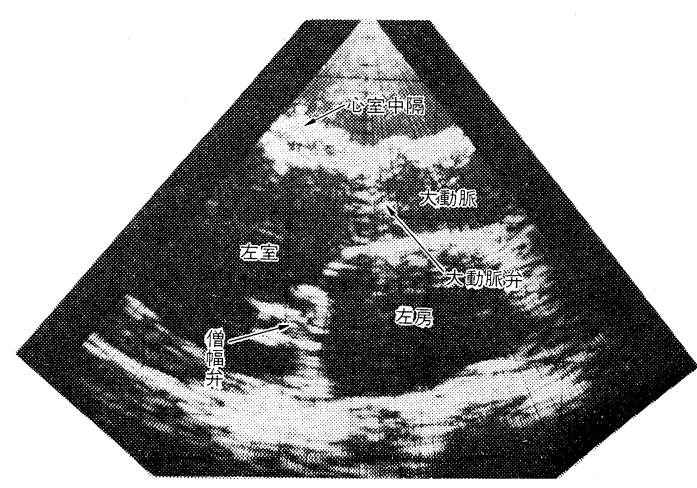

写真 5 セクター電子スキャンによる心臓長軸断層像 （僧帽弁狭窄と大動脈弁狭窄の連合弁膜症）

その動きを観察することにより心臟動態や血流の状態を 探知する方法である。コントラスト剂には生理的食湓水 やブドウ糖などが用いられ，末梢静脈からと心カテーテ ルを通して注入する方法がある。

前者は，右心系の㗨患 (三尖弁閌鎖不全狭窄，肺動脈 弁疾患, 先天性の短絡を有するむの) の診断に, 後者は 右心系のみならず左心系の疾患(僧帽弁, 大動脈弁など の疾患，先天性の短絡を有する疾患など）の診断に用い られている。

最近，このコントラスト法は， U.C. G と心臟断層法 との併用により, 異状流の性質, 逆流や短絡流の量的評 価，また流速や流量の計測など，定量的測定へと発展し つつある。

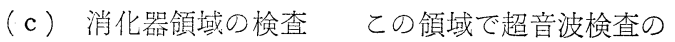




\section{2. 超音波画像技術の応用}

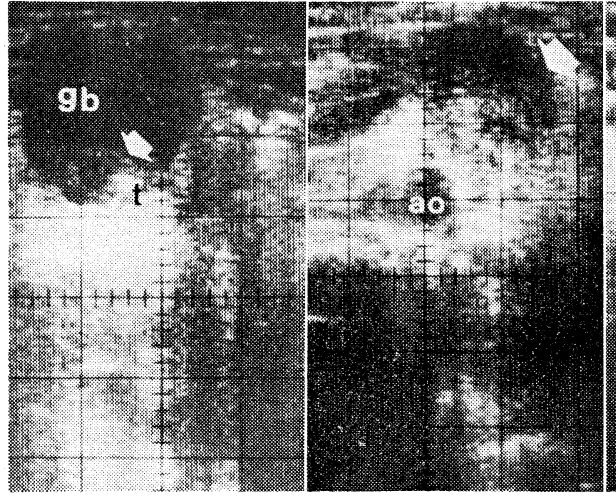

胆凉癌 $(\swarrow)$

䏽臟尾部癌 $(\swarrow)$

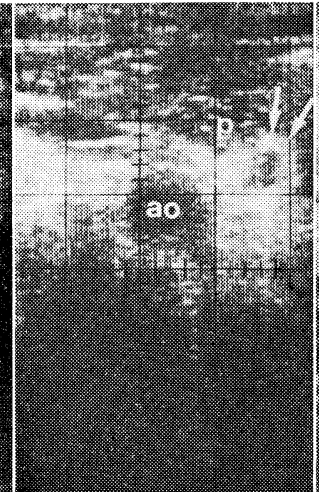

脺尾部後部リンバ節転移 $(\swarrow)$

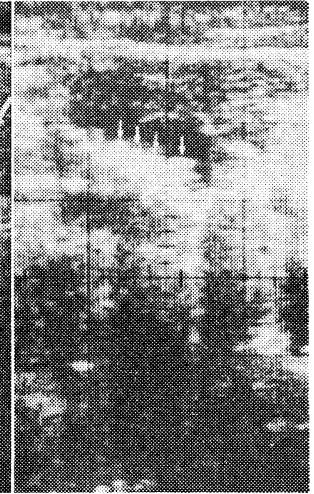

胆石癌 $(\swarrow)$

写真 6 リニア電子スキャンによる消化器疾患のエコーグラム $(\mathrm{gb}$ : 胆覀, $\mathrm{ao}$ ：大動脈, $\mathrm{p}$ : 膵藏)

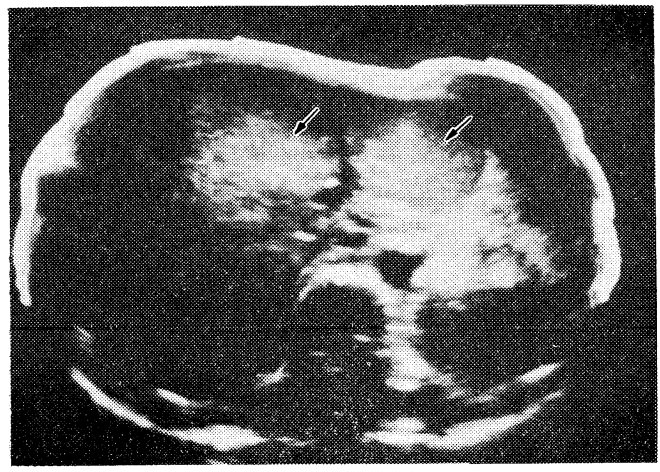

写真 7 C.C. Scan で記録した転移性肝癌 (ん)の エコーグラム

対象となる臟器は, 肝・膵・脾などの実質性臟器と胆道 であり，食道・胃・腸などの管腔藏器はガスの貯溜のた め超音波検查には不適である。疾患別では腫瘍（リンパ 節転移を含む)・結石症・慢性炎症などが対象になる(写 真 6 ).

使用される装置は，従来，主に手動走査形装置が用い
られてきた。この装置は皮膚に探触子を接触させ手動で 走查することから接触複合走査法 (C. C. Scan) と呼ばれ ている. この C.C. Scan の長所は，像が緻密かつ鮮明 であること，1回の走査で得られる視野が広いために， 周辺藏器との位置関係を含めた全体像が得られること

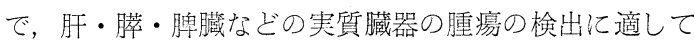
いる(写真 7 ).

しかし探触子の操作に熟練を要することと，実時間で 観察することができない欠点があるため，呼吸性に移動 しやすい臟器や位置異常の多い臟器には不適当である. この点, 電子スキャンは実時間で観察でき，かつ探触子 の操作が簡便で熟練を要しないため, 種々の部位や角度 からビームを走査することができ，肝内血管，胆囊，胆 管などの観察に適している(写真 8 ).

したがって腹部の検査においては，スクリーニングと して電子走查形を用い, 走査位置や角度を決定した後, C. C. Scan により, 再度断面像を描写するなど被検臟器 や疾患によって両装置が使い分けられている。乙の領域
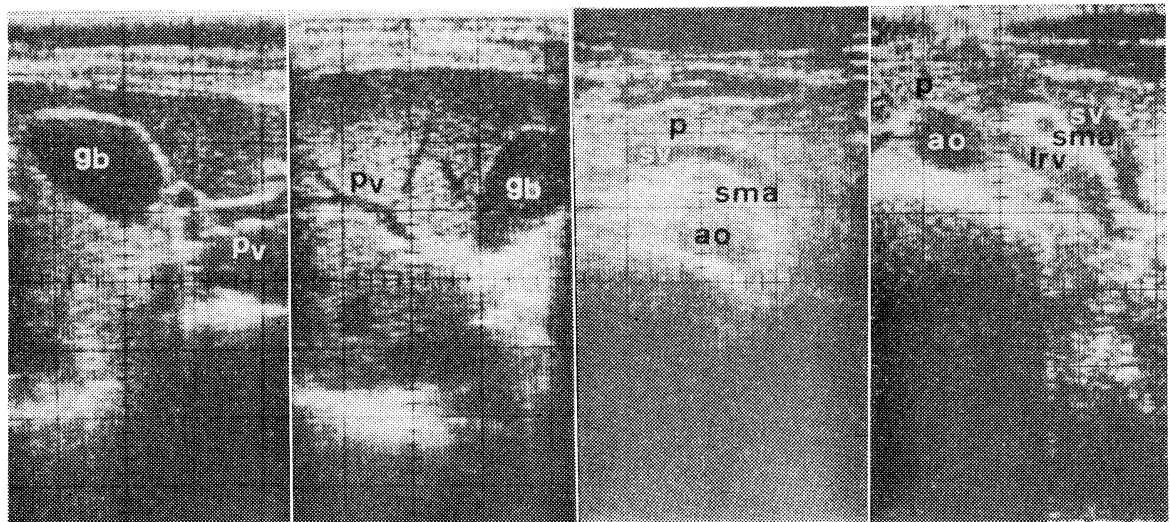

写真 8 リニア電子スキャンによる各種血管像

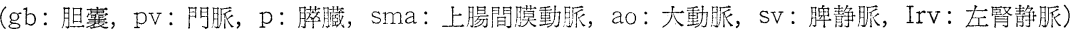




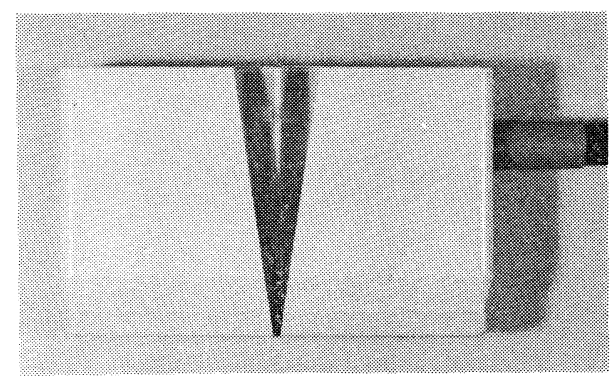

写真 9 リニア電子走查形臟器穿刺用探触子 （中央に穿刺針を道す溝がある）

の検査には，通常リニア走査形の電子スキャンが用いら れている。

ついでながら，乙こで電子スキャンの利点を生かした 新しい利用法を紹介すると，まず第一は，肝・胆道系の 集団検診への導入である，従来は経口胆囊造影法があっ ぱら用いられていたが，造影剂による副作用やX線被曝 の問題があるうえ, 胆囊の描写率や小結石の検出率が超 音波に劣り，さらに超音波検査では，膵・腎・脾などの 周辺重要藏器む同時に簡単にチェックできることから, 経口胆囊造影法にとって代わりつつある現状である.

第二は，各種穿刺法の利用である。乙れは“超音波穿 刺術” (Ultrasonically Guided Puncture) とも呼ばれ， 超音波映像をガイドに臟器を穿刺する方法で(写真 9)

(1) 胆管・膵管; 脈管などの造影

(2) 組織や細胞の㨙取

(3) ドレナージ

などを行う場合に利用されている.

第三は，術中診断への応用である．乙の方法は，現用 の電子スキャンの探触子を改良して小形化したむのを用 いて，術中，たとえば肝などに直接あてて腫瘍の浸潤 度, 門脈, 肝静脈などとの関係をリアルタイムに観察し ながら切除範囲を決定するすので，肝㵴手術などの分野 に利用され始めている.
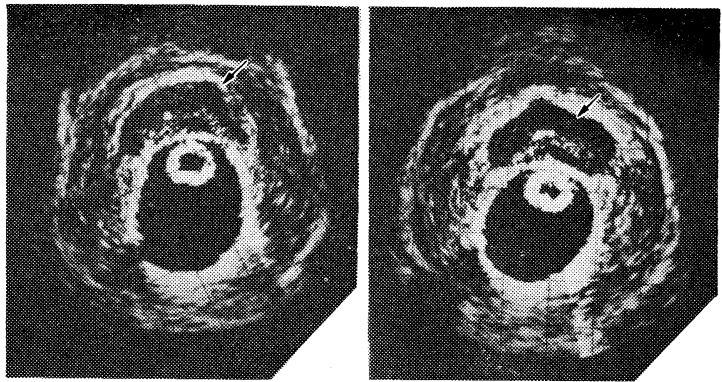

写真 11 経直腸的ラジアル走查で記録した正常前立腺像 $(\swarrow)$

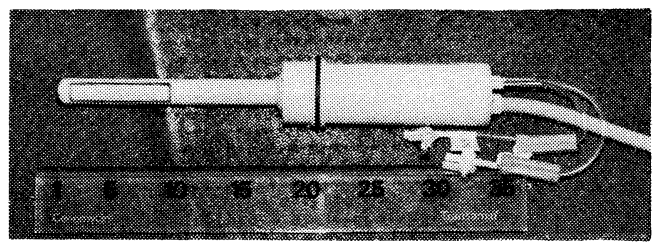

写真 12 経直晹絽断層法老行うために開発した探触子 (リニア電子スキャン)

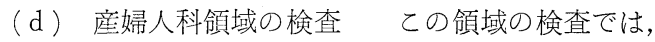
前述した消化器領域の場合亡同様, 従来加ら C. C. Scan が主に使用されていたが，最近りニア電子スキャンが活 用され，子宮内胎児の運動・畸型など診断目的が搪大さ れている(写真 10).

（e）泌尿器科領域の検査腎腫瘍や腎囊胞などの 腎疾患や副腎腫㿑の検査には，C. C. Scan や,リニア電 子スキャン, セクター電子スキャンが用いられているが, 膀胱・前立腺・精囊などの疾患にはラジアルスキャンに よる経直腸超音波診断装置が用いられている.

この方法は, 被検者の肚門より直腸内にゴムバルーン で包まれた探触子を挿入し, 脱気水を注入してバルーン を脹らませ，挆触子を機械的に $380^{\circ}$ 回転して，任意の 高さでの断面像を描かせるむのである(写真 11). 最近 では, 経直晹用のリニア電子スキャンの探触子 (写真 12) が開発され，一段と使用が簡便化された。
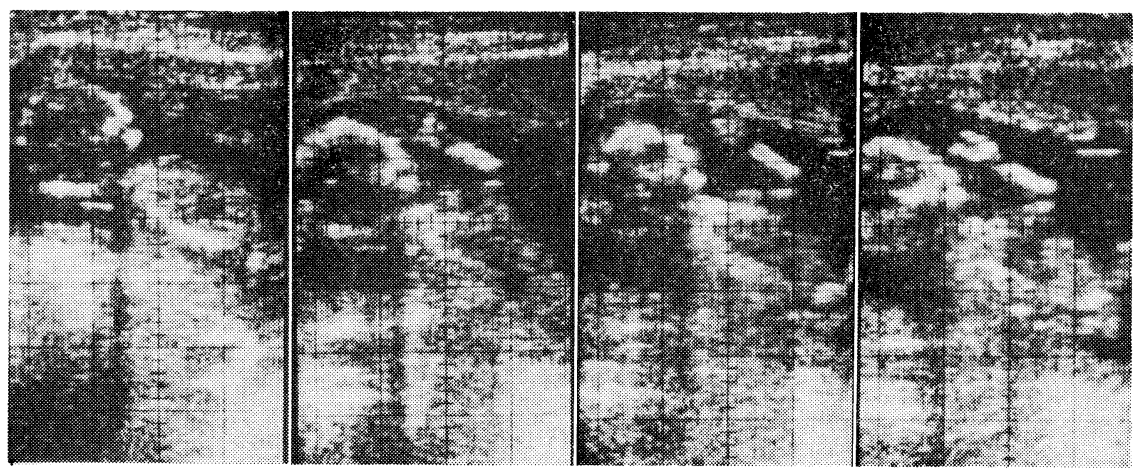

写真 10 リニア電子スキャンでコマ撮りした連動する胆児像（15 週 4 日） 


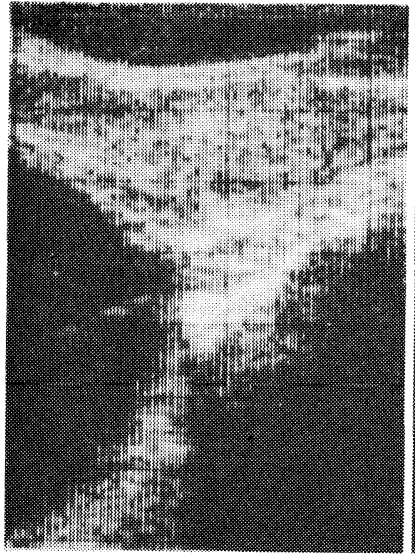

右 30 度

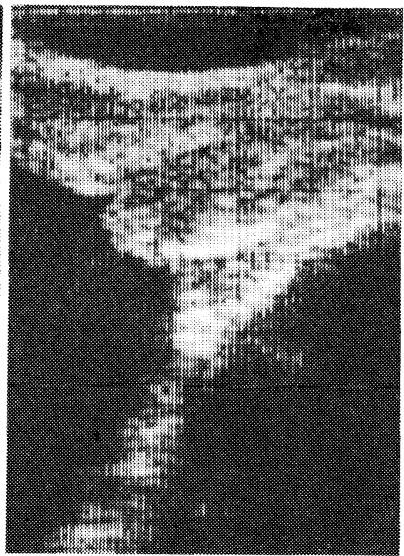

正中

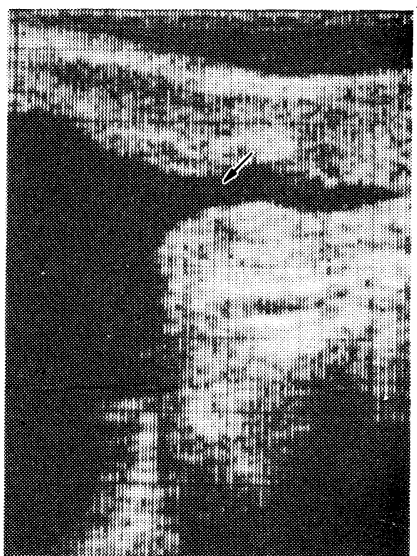

排尿時 ( $く$ 㽷道)

写真 13 経直腸的リニア電子走査形採触子を用いて記録した正常前立腺縦断層像

表 2 現在一般的に䒠施されている超音波検査の適応範囲之使用装置の種類

\begin{tabular}{|c|c|c|c|}
\hline 領 & 域 & 疾患または検査対象 & 使用装置の種類 \\
\hline 頭 & 部 & $\begin{array}{l}\text { 正中線エコーの検出, 頭蓋内血腫, 脳腫瘍, 水頭症, 頭蓋内拍動性 } \\
\text { エコ一の検出 }\end{array}$ & A, 拍動エコー曲線 \\
\hline 眼 & 科 & 眼軸長測定, 眼球異物, 出血, 網膜剝離, 眼窩腫瘍 & $A, B($ 手, 機 $($ 低 $))$ \\
\hline 耳鼻咽喉和 & & 側頸部腫瘍 ultrasono-glottography & $\mathrm{B}$ (機(低)リ, ア), M \\
\hline 甲 状 胿 & 腺 & 甲状腺腫瘍, 甲状腺重量測定 & B (機(低)リ，ア） \\
\hline 乳 & 腺 & 乳腺腫瘍 & B (機(低)り, ア) \\
\hline 心 & 臟 & 先天性疾患, 各種弁疾患, 心筋疾患, 心囊炎, 血流測定 & $\mathrm{B}$ (機(高)七, 電セ) $\mathrm{M}$ (U.C. G.)ド(パ, M系) \\
\hline & 管 & 動脈瘤, 血流計測 & B (手，機(高)リ，電リ）ド (パ，M系) \\
\hline 肺・縦涫 & 隔 & 縦隔腫瘍 & B (手, 電, リ，七，機(高)セ) \\
\hline 胆 囊 胆 管 & 管 & 胆石症, 胆管結石, 胆囊 - 胆管腫瘍, 総胆管囊腫 & B （電リ，手，機(高)リ） \\
\hline 肝 & 臟 & 朋硬変症, 朋腫瘍 & B (電リ, 手, 機(高)リ) \\
\hline 膵 & 臟 & 慢性膵炎, 膵腫瘍 & B (電リ, 手, 機(高)リ) \\
\hline 脾 & 臟 & 脾腫 & B (電リ, 手, 機(高)リ) \\
\hline 腹部腫演全般 & & 大網腸問膜腫瘍, 後腹膜腫瘍, その他腹部腫瘍全般 & B (電リ, 手, 機(高)リ) \\
\hline 子宮・付属器 & & 子宮筋腫，卵巢腫湯 & B（電リ, 手, 機(高)リ) \\
\hline 産 & 科 & 娃娠早期唁断, 胎盤付着部位診断, 胎巟児頭計测, 骨盤計测, 異常妊娠 & $\mathrm{B}$ (電リ, 手, 機(高)リ), $\mathrm{A}$, ド(連), $\mathrm{M}$ \\
\hline 泌 尿 器 科 & 科 & 腎腫瘍, 水腎症, 前立腺肥大, 前立腺癌, 膀胱腫瘍, 精囊疾患, 副腎腫瘍 & B (手ラ, 機ラ, 電リ電セ) \\
\hline
\end{tabular}

(注) A：A E-ド表示装置

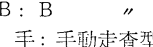

機(低)：低速機械走査型

機(高)：高速

電: 電子走査型
リ: リニア
セ: セクター
ア : アーク
ラ: ラジアル

この方式で得られる画像は，ラジアルスキャンの横断 面像に対して縦断面像になる。 そのうえリアルタイム表 示であるため膀胱頸部掞よび前立腺部尿道の動態観察が 可能になり，排尿機構の解明に大きな期待が寄せられて いる(写真 13).

（f） その他の領域 以上，述べた領域以外でBモ 一ド表示装置が利用されている分野は, 眼科・耳鼻咽喉 科で，眼科では $5 \mathrm{MHz}$ 以上の高い周波数の超音波を用 いた水浸法扇形走查が多く利用されている. 耳鼻咽喉科 では，通常対象となる疾患が側頸部腫瘍であるため乳腺 甲状腺用の装置が転用されている。

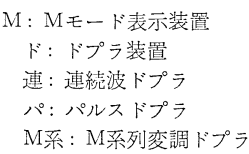

\subsection{M モード示装置}

これは運動体からのエコーの時間的変化を表示する方 式で，Bモードと同様にエコーをブラウン管上に輝度変 調し, 探触子を固定して時間軸の位置を移動して, エコー の経時的変化を記録する方式である，乙の装置は，循環 器領域で最も広く活用されており，心臟壁や弁の運動を 表す曲線を, とくに U. C. G. (Ultrasound Cardiography) 之呼び, 心電図之同様, 日常の心臟検查には不可欠の機 器になっている(写真 14)，最近でば前にあ述べたよう に，七クター電子スキャンに代表されるリアルタイム断 層法と併用され，高い臨床評洒を受けている. 


\section{4.む』ず}

超音波の診断的応用といえば，このパル ス反射法のほか，透過法，ドップラー法が ある，前者には，ホログラフィーや超音波 カメラがあり，後者は，リアルタイム表示 法との複合走査で注目を集めているが，日 常の臨床応用には今一歩の感がある。また 現在，大いに期待され精力的に研究されて いるものに，超音波顕微鏡と CT がある. これらは早晚, 臨床に登場し, 今までの生 体映像法では得られない新しい情報を提供 してくれることであろう.

以上“超音波の診断的応用”之題して，現在最む広く 利用されているパルス反射法による生体映像について, その概略を紹介した，その使用範囲は表 2 に示すように

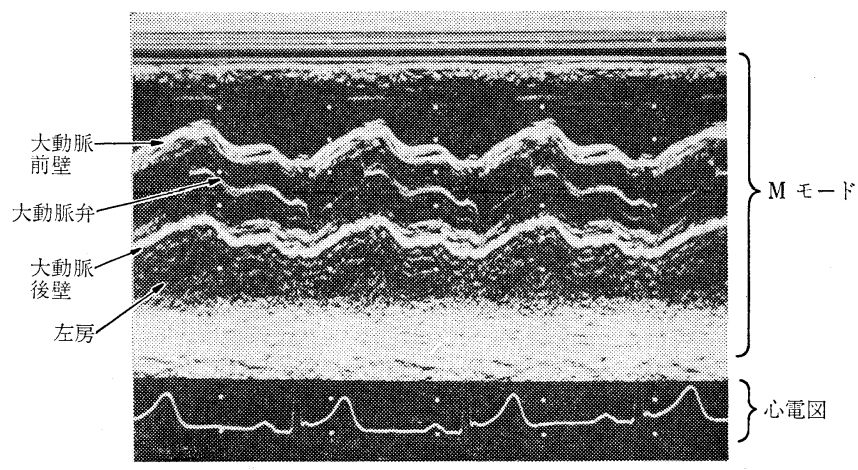

写真 14 正常大動脈弁の UCG CT, シンチグラフィーなどと共に 日常の診断に不可欠 の機器となっている. (昭和 55 年 10 月 17 日受付)

\section{2-2 水中視への応用}

\section{1. まえがき}

水中では, 可視光以外の電磁波はほとんど伝搬しない ため，観測または計測のための媒体としては使用できな い．可視光は比較的よく伝搬するが，濁度が高い埸合に は視程はごく短距離に限られてしまう。このため, 水中 での光学映像装置の使用は限られたものになる。

これに対して，海水中での音波の吸収は少なく，かな りの濁度の水中においても，周波数が $1 \mathrm{MHz}$ (波長が $1.5 \mathrm{~mm}$ ) の超音波によって数十 $\mathrm{m} の, 100 \mathrm{kHz}$ (波長が $15 \mathrm{~mm}$ ）の超音波によって数百 $\mathrm{m}$ の距離の観測が可能に なる. このため, 光の代りに超音波を用いて水中を観察 するための装置が種々開発されている.

\section{2. 映像ソーナーと超音波水中映像装置}

音波を用いて水中を観察するすのとして，乙れまでに あ漁業用に魚群探知機, 航海用および測量用に測深機, 海底地形観察用にサイドスキャンソーナー, 軍用に潜水 艦探知用ソーナー, 機雷探知機など, 各種の水中音響機 器（映像ソーナー）方使われている.

\section{†沖電気工業株式会社}

"2-2 Applications to Underwater Viewing" by Kazuhiko Nitadori

(Oki Electric Industry Co., Ltd., Tokyo)
似鳥一彦

これらはいずれもパルスエコー (パルス反射法) の原 理により画面の一方の軸を分解し, 音波の伝搬方向に沿 った面内を映像化するものであり，水中または海底の断 面像または海底面のボトムスキャン像を得るむのであ る.

これらによって水中の状沉はある程度把握できるが, 水中物体の形状を直観的に認識するのに充分な情報は得 られない,つまり, 従来の映像ソーナーと光学映像装置 の間には機能的に大きなギャップがあった。

このギャップを埋めるむのとして, 超音波を用いて光 学咉像装置之同様の正面像を得る超音波水中映像装置の 開発が進められている。

表 1 亿代表的な映像ソーナーおちよび超音波水中映像装 置の分類表を, 図1亿云礼らの送受波ビームの形状と走 查形式を示す.

(1)の測深機は, 細い棒状の送受波ビーム（ペンシルビ 一ム) を垂直下方に向汀て発生し, 得られるエコ一の時 間刘強度の関係を濃淡表示する, 送受波ビームと直角方 向の走查はプラットフォームの移動による. との移動と 記録機または表示器の水平軸の移動を同期させ，エコー の受信時刻と垂直軸の移動を同期させると，プラットフ ォームの航跡を通る垂直断面の映像が得られる.

(2)のボトムプロファイラーは，ペンシルビームを海底 